UDK 343.123(498)

Original scientific paper

\title{
TO CONTINUE OR TO GIVE UP THE PROSECUTION? CRIMINAL POLICY ASPECTS REGARDING THE PUBLIC INTEREST IN THE ROMANIAN PROCEEDINGS
}

\author{
Matei-Ciprian Graur, PhD, Associate Assistant \\ West University of Timisoara, Faculty of Law \\ Blvd. Eroilor 9A Timisoara, 300575 Timis, Romania \\ matei.graur88@e-uvt.ro
}

\begin{abstract}
To punish or to forgive? This is the problem that the state has to answer every time it faces the violation of the criminal law norms by a certain individual. The obligation to take criminal responsibility, to collect evidence ex officio, to initiate the procedures for sanctioning those who commit such acts become notions attenuated by the possibility of appreciating the opportunity of criminal prosecution.
\end{abstract}

As noted in the doctrine, referring to the Resolution of the Fourteenth International Congress of Criminal Law in Vienna of 1989, "the need for a social reaction to the small crime (petite delinquance), understanding here the facts that formally they fulfill the conditions of an offense, but that by the minimum attainment brought to the social values does not justify the application of a punishment, has determined to find alternative solutions to the criminal penalties."

Therefore, depending on the ethical specificity we are in, different alternatives to criminal prosecution will have to be implemented, as it will not be possible to prosecute any criminal act, even of very small significance.

In this regard, it was established at European level that "prosecutors should consider, if appropriate and in accordance with the law, alternatives to criminal prosecution".

One of the main ways of accelerating the criminal process is to give up the criminal prosecution, expressly regulated by the Code of criminal procedure in the provisions of art. 318 Criminal Procedure Code starting with 2014, thus outlining a special form of stopping the criminal process.

Keywords: give up the prosecution, to punish, to forgive, opportunity of criminal prosecution 


\section{IS CRIMINAL PROSECUTION COMPULSORY?}

Each state pursues, through its own criminal policy, the responsibility (harsher or more severe) of those who commit criminal acts, thus having a margin of appreciation of the procedural means of achieving this objective. ${ }^{1}$ This assessment will be based on a number of factors (different from state to state), such as economic, social, demographic, but also historical ones, as it is very difficult (and perhaps even undesirable) for an absolute unification of the criminal prosecution practice. ${ }^{2}$

It has been stated in the doctrine $e^{3}$ that "the law order corresponds more or less to the interests, motivations, general aspirations of the concrete societies and, therefore, it is specified: one is the law order in Sparta and another in Athens. You cannot ask for identity of law order in the Incas, as in the Danes, not even formal. Any ethical order of concrete law is the legal order modified privately and the public one, between them the connections acquiring differentiated contents."

Professor I. Deleanu stated in his paper ${ }^{4}$ that "the cumulative conditional elements of the emergence, disappearance and resurrection of the state are three: the nation, the territory, the exclusive or sovereign political authority. It does not investigate the attributes of the state, but the attributes of the Romanian state, as Bergel discusses his own modern French law."

Radclliffe-Browne argued" that "law would be a type of social control that is appealed by the systematic use of the force of an organized political society." Part of the doctrine $e^{6}$ considers such an idea as random, stating that "the theory may have coverage for example in the United Kingdom, not in China."

However, beyond the obvious controversies of the indicated problem, we agree with the existence of a wide and diversified range of approaches in the legal order of each individual state, making it very difficult to accept a uniform variant.

Therefore, depending on the specific ethics we are in, different alternatives to criminal prosecution will have to be implemented, as it will not be possible to prosecute any criminal act, even of very small significance.

Extract from Graur, M.C., Criminal action - between official and opportunity, Ed. Hamangiu, Bucharest, 2019, p. 291 and next

2 For an analysis of the state's right to punish, see L. Proal, Le crime et la peine, quatrieme édition, Librairie Félix Alcan, Paris, 1911, p. 506

3 Gheorghe M., Foundations of Law. The theory of legal responsibility, vol. V, Ed. C.H.Beck, Bucharest, 2006, p. 150

4 Deleanu, I., Institutions and Constitutional Procedures, vol. II, Lugoj, 2000, p. 11

5 Gheorghe, op. cit., note 3, p. 150.

$6 \quad$ Ibid. 
The Constitutional Court, in its jurisprudence, established that "free access to justice implies access to the procedural means by which the act of justice is performed. The legislator has the exclusive competence to establish the rules for conducting the trial before the courts, a solution that results from the constitutional provisions of art. 125 paragraph 3 and art. 128 of the Constitution. No category of persons or social group can be excluded from the exercise of the procedural rights, but, considering special situations, the legislator can establish special rules of procedure, as well as modalities for exercising the procedural rights, so that the free access to justice does not mean access, in all cases, to all judicial structures and to all remedies." Also, the constitutional judges noted that "free access to justice does not mean that it must be ensured at all the judicial structures, because the jurisdiction and the remedies are established exclusively by the legislator, who can set special rules, taking into account special situations."

In this regard, it was established at European level9that "prosecutors should consider, if appropriate and in accordance with the law, alternatives to prosecution. They should be implemented with full respect for the legitimate rights and interests of the suspects and victims and provide the possibility of mediation or conciliation between the perpetrator and the victim. For this, prosecutors should pay greater attention to the nature and seriousness of the crime, the protection of the society and the personality and background of the offender."

To promote fairness, consistency and effectiveness of prosecutors' action, 10 "competent public authorities are encouraged to publish clear rules, guidelines and criteria for the effective and correct implementation of criminal policy regarding alternatives to prosecution. Alternative measures should never be used to circumvent the rules of a fair trial by imposing measures on an innocent person or who could not be convicted due to procedural obstacles, such as prescribing criminal liability. These measures should not apply even when there is doubt as to the discernment of the identified perpetrator or the extent of the harm caused by the crime."

D.C.C. nr. 1/1994, M. Of. nr. 69 from March 16, 1994

8 D.C.C. nr. 129/1995, M. Of. nr. 105 from March 23, 1996

$9 \quad$ Pct. 2.3 parag. 28-32 from Explanatory note to Opinion no. 9 (2014) of the Advisory Council of European Prosecutors

10 Parag. 29 și from from Explanatory note to Opinion no. 9 (2014) of the Advisory Council of European Prosecutors 
Minors are also receiving special attention, ${ }^{11}$ stating that, "given the negative impact that criminal or other procedures could have on the future development of minors, prosecutors should, whenever possible, and in According to the law, consider alternatives to criminal prosecution for juvenile offenders, where they can provide an adequate legal response to the crime, taking into account the interests of victims and the general public, as well as the objectives of the juvenile justice system. Prosecutors should do their utmost to start criminal proceedings against minors only when strictly necessary."

This approach is yet another example where the appreciation of the public interest in juvenile matters (through the concrete application of the principle of opportunity) must be harmonized with the principle of legality (in accordance with the law).

As stated in the doctrine, ${ }^{12}$ "no person free and responsible for his actions can be legally held legally liable unless it is found that certain conditions established in this sense by the law itself, in the stateized society are met." Starting from this idea, we agree with the position of the author, who argues that the statement "any responsible person is obliged to be held legally responsible for the consequences of his legal facts" is ambiguous.

Even if it is inevitable that we should accept that this should be the rule, we cannot help but ask the following question: Is it appropriate to bring criminal liability every time and by any means?

The answer, of course, will have to be a negative one, precisely applying the criteria of opportunity outlining exceptions to the rule of unconditional punishment.

\section{CONDITIONS FOR WAIVING CRIMINAL PROSECUTION}

The conditions ${ }^{13}$ under which the prosecutor can give up the criminal prosecution are foreseen in a limited way, the doctrine emphasizing that the necessity of imposing conditions in the application of the opportunity analysis aims to: ensure transparency and remove any arbitrariness in the provision of measures that actually represent criminal policy options of the To the Public Ministry, ensuring efficient judicial control of the prosecutor's solutions based on the principle

\footnotetext{
$11 \quad$ Pct. 2.3 parag 31 și 32 from Explanatory note to Opinion no. 9 (2014) of the Advisory Council of European Prosecutors

12 Gheorghe, op. cit., note 3, p. 152

13 Graur, op. cit., note 1, p. 297
} 
of opportunity, avoiding the excessive increase of the prosecutor's powers, which otherwise could have become the main actor in the criminal policy of the state. ${ }^{14}$

Reported on the conditions that must be fulfilled in the situation of disposing of a solution of renouncing the criminal prosecution, art. 318 para. 1 Code of Criminal Procedure establishes that "in the case of offenses for which the law provides for the penalty of the fine or the sentence of imprisonment for a maximum of 7 years, the prosecutor may renounce the criminal prosecution when he ascertains that there is no public interest in prosecuting it". Paragraph 2 establishes the criteria in relation to which the public interest will be analyzed, establishing that the "content of the deed and the concrete circumstances of its commissioning, the manner and means of committing, the purpose pursued, the consequences produced or what could have been taken into consideration" produces, the efforts of the criminal investigation bodies necessary for carrying out the criminal trial by reference to the gravity of the crime and the time elapsed from the date of its commission, the procedural attitude of the injured person or the existence of a clear disproportion between the expenses that would involve the conduct of the criminal trial and the gravity the consequences that may have occurred or which could have occurred through the commission of the crime ". "There will be no solution to waive the criminal prosecution in the case of offenses which resulted in the death of the victim", according to art. 318 para. 5 Code of criminal procedure.

From the content of the indicated legal text it follows that it is necessary to strictly comply with some conditions expressly provided by the law, conditions that must be met in order for the prosecutor to take into account the disposition of a solution for renouncing the criminal prosecution. In this respect, the conditions listed above relate to the admissibility of a waiver solution, creating for the suspect or the defendant a vocation for such a solution, by no means an absolute right.

The conditions stipulated by the law that must be fulfilled in order to be able to order a solution to renounce the criminal prosecution are the following:

- the criminal prosecution in question was initiated;

- criminal prosecution to target an offense for which the law stipulates the penalty of the fine or the sentence of imprisonment for a maximum of 7 years;

- the prosecutor finds that there is no public interest in pursuing the deed.

Thus, following the analysis by the prosecutor of the set of criteria and conditions listed by the legislator in the provisions of art. 318 para. 1-5 Criminal procedure

14 Volonciu, N.; Uzlău, A., Code of Criminal Procedure commented, Ed. Hamangiu, Bucharest, 2014, p. 22 
code, it can adopt a solution of renouncing the criminal prosecution, but can, at the same time, continue the process, considering that it is not necessary to stop it.

Therefore, the possibility of appreciation that the prosecutor has in the hypothesis of analyzing a potential solution of renouncing criminal prosecution gives rise to an important procedural moment in which the criminal prosecution bodies are called upon to assess subjectively whether it is appropriate to carry out further prosecution.

\section{THE PUBLIC INTEREST}

The criteria according to which the case prosecutor appreciates the opportunity for a solution to renounce the criminal prosecution are included in the provisions of art. 318 Criminal Procedure Code..$^{15}$

From the beginning, it should be emphasized that art. 318 The Criminal Procedure Code is the only legal text within which the conditions of public interest are specified, as there are no other internal norms of law that guide the judicial bodies in assessing the opportunity of the solution. ${ }^{16}$

We specify that the provisions of art. 318 Criminal Procedure Code has undergone important changes following the adoption of O.U.G. no. 18/2016, the ordinance restating including the criteria regarding the assessment of the public interest. ${ }^{17}$

Subsequent to the amendments made by the above mentioned ordinance, art. 318 Criminal procedure code stipulates in the par. 2 the fact that "the public interest is analyzed in relation to:

a) the content of the deed and the concrete circumstances of the deed;

b) the manner and means of committing the deed;

c) the purpose pursued;

15 For a broad presentation, see: Graur, op. cit. note 1, p. 310 and next

16 We mention that the phrase public interest is used by the legislator and in the field of administrative law, also benefiting from a legal definition, by the provisions of art. 2 paragraph (1) lit. 1) of Law no. $554 / 2004$ of the administrative litigation, with the subsequent modifications and completions

17 Prior to the entry into force of the O.U.G. no. 18/2016, the text of the law provided that "in the case of offenses for which the law stipulates the penalty of the fine or the sentence of imprisonment for a maximum of 7 years, the prosecutor may renounce the criminal prosecution when, in relation to the content of the deed, the manner and means of committing, with the consequences produced or that could have occurred through the commission of the crime, finds that there is no public interest in prosecuting it. "The text also stipulated that "when the perpetrator is known, the person of the suspect or the defendant, the conduct prior to the crime and the efforts made to remove or mitigate the consequences of the crime are taken into account when assessing the public interest." 
d) the consequences produced or that could have occurred by committing the crime;

e) the efforts of the criminal investigation bodies necessary for carrying out the criminal trial by reference to the gravity of the deed and to the time elapsed from the date of its commission;

f) the procedural attitude of the injured person;

g) the existence of a manifest disproportion between the expenses that would involve the carrying out of the criminal trial and the gravity of the consequences produced or that could have been produced by committing the crime."

Also, as in the case of the provisions preceding the amendments, the law provides that "when the perpetrator of the crime is known, the person of the suspect or the defendant, the conduct prior to the crime, the attitude of the suspect or the defendant are taken into consideration in the assessment of the public interest. after the crime was committed and the efforts made to remove or diminish the consequences of the crime".

We notice that the new regulation enumerates in a broader way the criteria for the appreciation of the public interest. Thus, the new ones mentioned in letter no. e-f of art. 318 para. 2 Code of criminal procedure.

The recent doctrine ${ }^{18}$ referred to a classification of the criteria of the public interest, bringing to the fore four types of such criteria, which differ from the contents of art. 318 Criminal Procedure Code.

Thus, the criteria for evaluating the public interest can be classified as follows:

- Criteria for the offense;

- criteria for the offender;

- criteria for the costs of criminal prosecution;

- criteria for the benefits of criminal prosecution.

All these elements for determining the public interest are confined even to the requirements of the Recommendation of the Committee of Ministers of the Council of Europe no. (87) 18 of September 17, 1987 on the simplification of

18 Udroiu, M., Criminal Procedure, The special part, 4th Edition, Ed. C.H. Beck, Bucharest, 2017, p. 107 
criminal justice, the national law approaching this time very close to the criteria highlighted at European level.

The natural question in these conditions, to which it is required in our analysis to find an answer, is whether these criteria, defined in the content of art. 318 Code of criminal procedure, are they or not limiting?

First, we mention that the phrase public interest does not have an express definition in the rules of criminal procedure.

Thus, the public interest will be analyzed at least by reference to the criteria mentioned above. The question may be asked whether these legal criteria, provided by art. 318 Code of criminal procedure, will they receive a limiting, rigid interpretation or will the prosecutor have the possibility of adding other conditions of assessment?

The contents of the Report ${ }^{19}$ refer to the public interest, establishing that it does not have an express definition, an aspect that cannot be invoked as a lack of predictability. In this regard, we consider the condition of the predictability of the procedural law fully respected, in accordance with the requirements of the ECHR, the Court asserting countless times that the drafting of a text of law should not have absolute accuracy, the text of law cannot be predictable with absolute certainty, experience demonstrating that such certainty cannot be imposed. ${ }^{20}$

The court made constant references to the fact that the predictability of the law does not preclude a gradual clarification of the law, does not prevent the person interested in resorting to the recommendations of specialists, and this does not require an exhaustive definition of all relevant terms. ${ }^{21}$

Naturally, the need for interpretations given to the law by the judicial bodies, which are the first to apply the rules of law in this matter, fully responds to the requirement of clarity and predictability of the criminal procedural law.

To answer the question posed above, so in order to establish the character of the criteria listed by the legislator in art. 318 Criminal procedure code, we will consider the position of the Court in a famous case against Romania in the matter of

19 Report of P.I.C.C.J., Short references on theoretical and practical approaches made by the P.I.C.C.J. since the entry into force of the New Codes in order to understand and apply the principle of opportunity correctly and uniformly, p. 32, [www.mpublic.ro], accessed on 04. July 2016

20 In this respect, see the Sunday Times c. Great Britain, 26 April 1979, Parag. 49, Kokkinakis c. Greece, May 25, 1993, Parag. 40, Cantoni c. France, November 15, 1996, Parag. 32, Rekvenyi c. Hungary, Parag. 34, [www.echr.coe.int], accessed on 04. July 2016

21 Report of P.I.C.C.J., p. 32 
predictability. ${ }^{22}$ The Court recalls, reiterating the principles set out in other cases, ${ }^{23}$ that "the significance of the notion of predictability depends to a large extent on the content of the text in question, on the field it covers, as well as on the number and quality of its recipients. The predictability of the law does not preclude the idea that the person concerned should be determined to use clear guidance in order to be able to assess, to a reasonable extent in the circumstances of the case, the consequences that could result from a certain fact.

"Also, the Court found "both in the aforementioned judgment and in its previous settled case-law, that precisely in view of the principle of generality of laws, their formulation cannot have absolute accuracy. One of the regulatory-type techniques is the use of some categories rather general than exhaustive lists. Thus, many laws are used by the force of things of more or less vague formulas, in order to avoid excessive rigidity in order to adapt to the changes of situation. The interpretation and application of these texts depends on the practice. ${ }^{24}$

The court also stated that "the decision-making function entrusted to the courts serves precisely to remove any doubts that may remain regarding the interpretation of the rules, taking into account the evolution of daily practice, provided that the result is consistent with the substance of the crime and reasonably foreseeable. ${ }^{25}$ "

Therefore, even if the public interest does not receive an express definition in the legal text, the fact that it can be determined by using certain criteria set by the legislator marks the observance of the predictability of the procedural norm.

As stated in the doctrine ${ }^{26}$, "the necessity of imposing conditions in the application of renouncing criminal prosecution is aimed at: ensuring transparency and removing any arbitrary provision of measures that represent in fact criminal policy options of the Public Ministry, ensuring efficient judicial control of the the prosecutor's solutions based on the principle of opportunity, avoiding the excessive increase of the prosecutor's powers, which otherwise could have become the main actor in the criminal policy of the state."

22 Dragotoniu and Militaru-Pidhorni c. Romania, 24 May 2007, Parag. 35 and next, [www.echr.coe.int], 04. July 2016

23 In this regard, see Groppera Radio AG and others c. Switzerland, 28 March 1990, Parag. 68, [www. echr.coe.int], 04. July 2016

24 Considerations resumed by the Court also in Kokkinakis c. Greece, 25 May 1993 and Cantoni c. France, 15 November 1996, [www.echr.coe.int], accessed on 04. July 2016

25 Considerations resumed by the Court also in S.W. c. United Kingdom, 22 November 1995, Parag. 36, [www.echr.coe.int], accessed on 04. July 2016

26 Udroiu, M., Code of Criminal Procedure. Comment on the articles, Ed. C.H. Beck, Bucharest 2015, p. 59 
It was stated ${ }^{27}$ that these general criteria were established "in order to avoid the arbitrary disposition of the solution of renouncing the criminal prosecution by the prosecutor", and in all cases, the opportunity should be related only to the public interest, in which reasons must not be found for "political opportunity".

Therefore, it has been correctly stated in the Report ${ }^{28}$ that, although not expressly defined, the notion of public interest is "definable (its content can be identified)". Thus, it was shown ${ }^{29}$ that "justice is a public service that responds to a public interest (the realization and enforcement of the law order), a public interest which, in a criminal trial (regarded as one of the particular forms of justice), consists in identifying the facts. antisocial acts that constitute crimes, of the persons who committed them and the criminal liability, according to the law, a law that reflects the conception of the state on the basis of its right to punish (exclusively the feeling of justice as a foundation of the right to punish, reflected in the principle of legality / obligation of criminal prosecution or exclusively the social utility as a basis of this punitive right, reflected in the principle of availability or the combination of the two principles."

We note that the new conception of opportunity can give the impression of a dilution, to a certain extent, of the applicability of the principle of legality. In this regard, it is important to emphasize that the principle of legality will not be confused with that of the obligation of criminal prosecution. Specifically, the fact that the prosecutor will appreciate that the public interest does not require the pursuit of a certain fact (or of a certain perpetrator, if we guide ourselves according to the criteria of the public interest in relation to the person who committed the deed) will not mean that the principle of legality is not respected.

On the contrary, applying the opportunity in a situation where, perhaps, some time ago the obligation of criminal prosecution was imposed, will succeed in respecting the legality of the criminal process precisely because the organic law (the criminal procedural provision) provides for such a possibility.

As long as the prosecutor will respect the criteria established by art. 318 Code of criminal procedure in the assessment of the public interest, the solution of the classification in opportunity can only be a legal one.

Ibid., p. 60

28 Report of P.I.C.C.J., p. 32

29 Report of P.I.C.C.J., p. 32 
The French doctrine of public law ${ }^{30}$ has consistently shown that the public interest is the cornerstone of political and legal thinking, being considered the ultimate goal of public action. Therefore, the public interest was considered a common ideal, materialized through the collective satisfaction of the common social values. ${ }^{31}$

Therefore, we appreciate that even in our domestic legislation, the identification of the criteria of public interest could be made by reference to the provisions contained in art. 318 Criminal Procedure Code. Thus, we do not think that it can be claimed that the public interest will be determined strictly according to the criteria of paragraphs 2 and 3, being able to imagine us also situations in which the prosecutor identifies another criterion, expressly provided by law, but which satisfies the legal requirements. . Of course, in this hypothesis the problem of a possible addition to the law can be posed, the extension of the criteria could become dangerous in terms of the predictability and legality requirements.

We can consider, however, that the prosecutor is not bounded by the criteria mentioned above, but any other new criterion, not explicitly identified in the text of law, should however be limited to one of the ones provided in par. 2 and 3 of art. 318 Criminal Procedure Code.

We support this in view of the changes made by the O.U.G. no. 18/2016, which increased the scope of appreciation of the public interest, adding other criteria, previously unforeseen. However, from their analysis, it turns out that they are nothing more than general criteria, which cover to a large extent the requirements of the public interest assessment.

By Decision No. 23 of 20 January 2016 32 , the Constitutional Court resolved the exception of unconstitutionality of the provisions of Art. 318 Code of Criminal Procedure.

In relation to the criticisms made, the Court began its analysis by reference to the phrase public interest in Art. 318 par. 1 Code criminal procedure, criticism that it would be ambiguous, not defined in the Criminal Procedure Code or Criminal Code. ${ }^{33}$

Therefore, what the Court had to do first was to ascertain whether the text criticised contains sufficient evidence to determine the content of that phrase.

\footnotetext{
30 Rapport public du Conseil d'État, Etudes at documents, no. 5, 1999, [www.conseil-etat.fr], 30. January 2018

31 See Report of P.I.C.C.J., p. 33 și urm

32 Published in the Official Gazette no. 240 of 31.03 .2016

33 The recitals of the Decision examined at length in Graur, op. cit., note 1, p. 318 and next
} 
Thus, the analysis was started by reference to Decision No 732 of 16 December $2014^{34}$ in order to establish the requirements for clarity, precision and predictability of the criminal procedural law. The Court held that "the recipients of the criminal norm of criminal criminalisation must have a clear representation of the constituent elements, of an objective and subjective nature, of the offense, so that they can foresee the consequences resulting from failure to comply with the norm and adapt their conduct according to it". It is also referred to paragraph 29 of the same decision, where the Court held that "the essential feature of the rule of law is the supremacy of the Constitution and the obligation to respect the law". The Court also held in other decisions ${ }^{35}$ that "the rule of law ensures the supremacy of the Constitution, the correlation of all laws and all normative acts with it. This aspect implies that the rule of law is an excellent state in which the rule of law is manifested." 36

At the same time, the Court took into account Decision No 1 of 10 January 2014, published in the Official Gazette No. 123 of 19 February 2014 (Parag. 225), where he noted that "one of the requirements of the principle of compliance with laws relates to the quality of normative acts and that, in principle, any normative act must satisfy certain qualitative conditions, including predictability, which implies that it must be sufficiently clear and precise to be applied. Thus, the wording with sufficient precision of the normative act allows the persons concerned, who may, if necessary, appeal to the advice of a specialist, to provide to a reasonable extent, in the circumstances of the case, the resulting consequences." ${ }^{37}$

As regards the case law of the European Court of Human Rights, the Court referred to the judgments of 4 May 2000, 25 January 2007, 24 May 2007 and 5 January 2010, delivered in Rotaru v. Romania (Parag. 52), Sissanis c. Romania (Parag. 66), Dragotoniu and Militaru-Pidhorni c. Romania (Parag. 34) and Beyeler c. Italy (Parag. 109) ${ }^{38}$, in order to analyse the quality of the law as a guarantee of the principle of legality. In these judgments it was noted "the obligation to ensure these standards of quality of the law as a guarantee of the principle of legal-

\footnotetext{
34 Published in the Official Gazette no. 69 of 27 January 2015 (Parag. 25)

35 Decision No. 232 of 5 July 2001, published in the Official Gazette no. 727 of 15 November 2001, Decision No. 234 of 5 July 2001, published in the Official Gazette no. 558 of 7 September 2001, Decision no. 53 of 25 January 2011 published in the Official Gazette no. 90 of 3 February 2011

36 For this purpose, see Decision No 13 of 9 February 1999, published in the Official Gazette No 178 of 26 April 1999

37 To that end, see Decision No. 903 of 6 July 2010, published in the Official Gazette No. 584 of 17 August 2010, Decision No 743 of 2 June 2011, published in the Official Gazette No. 579 of 16 August 2011, Decision No 1 of 11 January 2012, published in the Official Gazette No 53 of 23 January 2012, Decision No 447 of 29 October 2013, published in the Official Gazette no. 674 of 1 November 2013

38 Online at [www.echr.coe.int], accessed on 17. July 2016
} 
ity, provided by Article 7 of the Convention. ${ }^{39 "}$ Thus, it is recalled that "the position of the European court in Sissanis v. Romania (Parag). 66), where it has been noted that the phrase provided by the law requires that the measure criminalised must have a basis in national law, but it also concerns the quality of the law in question - it must be accessible to the individual and predictable with regard to its effects. Furthermore, in order for the law to satisfy the requirement of predictability, it must specify with sufficient clarity the extent and modalities of exercising the discretion of the authorities in that field, taking into account the legitimate aim pursued, in order to provide the person with adequate protection against arbitrariness'. It was also stated that "the law can only be regarded as a rule laid down with sufficient precision in order to allow the citizen to control his conduct. The citizen may resort to the need for expert advice in this matter, but he must be able to reasonably foresee the consequences of the case, which could result from a certain fact."

In the case of Rotaru c. Romania (Parag. 52), the European Court recalled its settled case-law, according to which 'the law means not only a certain legal basis in national law, but also the quality of the law in question, and thus it must be accessible to the person and predictable'. Also in the case of Dragotoniu c. Romania (Parag. 34), it was stated that "the concept used in Article 7 of the Convention corresponds to the concept of law appearing in other articles of the Convention, and it encompasses the right of origin both legislative and case-law and implies qualitative conditions, inter alia, of accessibility and predictability."

The Constitutional Court continues to treat the phrase public interest ${ }^{40}$, starting from the analysis previously carried out in terms of predictability and accessibility of the law. She notes that "the listing in the provisions of Art. 318 par. 1 Code Criminal Procedure of the elements relating to the content of the act, the manner and means of committing, the intended purpose, the concrete circumstances of the commission and the prosecutions caused or which may have occurred by committing the offense, in addition to which Art. 318 par. 2 Code criminal procedure indicates that, when the perpetrator is known, the assessment of the public interest is to be considered for the criminal interest's being committed, and the offender's previous efforts are not to clarify the offender's efforts and the previous offenders.

Thus, the Court finds that "the meaning of the public interest is not determined by the legislator by the provisions of Art. 318 par. 1 and 2 Criminal Procedure

\footnotetext{
39 European Convention on Human Rights

40 Parag. 15 of the Decision
} 
Code, and the elements listed in them as criteria for determining the public interest are not such as to define the concept, which constitute criteria for individualisation of penalties, in case a court finds the commission of offenses."

The Court held in this regard that "the meaning of the public interest is not determined by the legislator by the provisions of Art. 318 par. 1 and 2 Criminal Procedure Code, and the elements listed in them as criteria for determining the public interest are not such as to define the concept, which constitute criteria for individualisation of penalties, in case the court finds the commission of some offenses." ${ }^{41}$

The Constitutional Judges took into account Decision No. 390 of 2 July 2014, published in the Official Gazette no. 532 of 17 July 2014 of the Constitutional Court ${ }^{42}$, where it was established that "a legal notion may have a different content and meaning autonomously from one law to another, provided that the law using that term defines it.

In the light of the foregoing, the Court held that "the legislator must lay down precisely the obligations of each judicial body, which must be circumscribed to the concrete way of carrying out their duties, by establishing, unequivocally, the operations which they perform in the exercise of their duties. ${ }^{43}$ In the resolution of the case, the prosecutor cannot depart from its content, making delimitations which fall within the competence of the legislative power." ${ }^{44}$

Therefore, the Court found that the text criticised "does not meet the standards of clarity, precision and predictability of the criminal law, violating the principle of legality of the criminal process, regulated by Art. 2 Code Criminal Procedure and therefore the provisions of Art. 1 par. 5 of the Constitution." ${ }^{45}$ According to the constitutional provisions, it establishes the obligation to respect the Constitution, its supremacy and laws in Romania.

Therefore, the Court found that "by regulating the institution of relinquishing the prosecution under Art. 318 Criminal Procedure Code, the legislator did not strike an adequate balance between the application of the principle of legality, specific to the continental law system, existing in Romania, and the application of the principle of opportunity, specific to the Anglo-Saxon legal system, giving prevalence to

\footnotetext{
41 Parag. 15 of the Decision

42 Parag. 31 of the Decision

43 Parag. 15 of the Decision

44 Ibid.

45 Parag. 16 of the Decision
} 
the latter, to the detriment of the former, by regulating among the powers of the prosecutor certain acts specific to the judicial power." 46

Thus, the Court establishes that "the prosecutor has the possibility to drop the criminal investigation and, consequently, to replace the court, in the performance of the judicial act, in the case of approximately three quarters of all the offences provided for in the Criminal Code and in the special laws in force."

The decision of the Constitutional Court on Opportunity - no. 23/20.01.2016, had legislative effects, declaring the provisions of Art. 318 Criminal Procedure Code as unconstitutional requiring the immediate modification of the legal provisions regarding the waiver of criminal investigation.

Thus, the adoption of the GO no. 18/2016 $6^{47}$, brought a new vision on the plan of relinquishing the prosecution, an early solution and at the date of the decision of the Constitutional Court.

Thus, Art. II, item 82 of the GO no. 18/2016 amended Art. 318 Criminal Procedure Code, essential being 2 aspects in the plan of relinquishing the criminal investigation.

Firstly, the modification increased the number of public interest criteria, increasing the scope of elements to be taken into account when assessing it by the case prosecutor, which I highlighted when discussing the conditions of public interest in the matter of opportunity.

Secondly, the institution was introduced to confirm the solution to waive the prosecution by the Preliminary Chamber Judge.

In this regard, the provisions of Art. 318 par. 12-16 Code criminal procedure establish this time the procedure for confirming the solution of renunciation, which remains final only after it has been verified by a judge.

The most important amendment was the correlative one of the essential criticisms of the decision of unconstitutionality, namely the regulation of the obligation to submit, ex officio, all solutions of renouncing the prosecution of the Preliminary Chamber Judge. ${ }^{48}$

\footnotetext{
$46 \quad$ Parag. 30 of the Decision

47 Published in M. Of. Number 389 of May 23, 2016

48 In this respect, see Barbu, A.; Tudor, G.; Şinc, A. M., Code of Criminal Procedure, Ed. Hamangiu, Bucharest, 2016, p. 665
} 
The need for such proceedings gave rise to controversy, given that, even before the amendment, the solution could be challenged by the person concerned with a complaint against the non-trial solution.

Moreover, the possibility of giving up on the grounds of opportunity, without a mandatory verification by a judge, was also provided for in the previous criminal proceedings ${ }^{49}$, when the prosecutor analysed the lack of social danger as a feature of the offense.

However, the adoption of a mandatory verification, in all cases, by the Preliminary Chamber Judge, of the solution to waive the criminal investigation, may appear as unjustified, especially if a series of criminal acts on which a solution to waive the criminal investigation will be ordered will be of little significance.

\section{THE PRINCIPLE OF OPPORTUNITY IN THE LEGISLATION OF OTHER STATES}

It is important in our endeavor to understand the origin of the opportunity, as a principle in the criminal process, by reference to other laws, in the wish to realize the concrete way in which the judicial bodies can (or sometimes are even obliged) to stop a criminal investigation in progress. ${ }^{50}$

Specifically, the materialization of the opportunity on a procedural level is achieved by renouncing the criminal prosecution, an institution regulated by the provisions of art. 318 Criminal Procedure Code.

The possibility of giving up the criminal prosecution is found, in different forms (some very similar to our legislation) in most states with principles of modern criminal law, the source of this institution being, among others, the overcrowding of prosecutor's offices with criminal cases which sometimes have a very small significance, but also the need to speed up procedures.

In this sense, relevant is the report of the Prosecutor's Office attached to the High Court of Cassation and Justice ${ }^{51}$, a report prepared and submitted to the Constitutional Court of Romania in 2015, when the constitutional judges analyzed the constitutionality of the provisions of art. 318 Criminal Procedure Code.

\footnotetext{
49 Prior to 1 February 2014

50 See Graur, M.C., Criminal action - between official and opportunity, Ed. Hamangiu, Bucharest, 2019, p. 275 and next

51 Online at [www.mpublic.ro], accessed on 27. June 2016
} 
In the mentioned report, brief references were made regarding the theoretical and practical approaches made by P.I.C.C.J. from the entry into force of the New Codes in order to understand and correctly and uniformly apply the principle of opportunity.

In order to make the prosecutor's activity more efficient in the P.I.C.C.J., at the level of the Prosecutor's Office attached to the High Court of Cassation and Justice, a comparative law study has been carried out, mainly in order to understand the mechanism of opportunity in the context of diversifying the principles in the criminal process.

Thus, if a few years ago, the judicial bodies did not conceive (mainly due to the regulatory tradition) "deviation" from the rules of legality and the truth, we are today in the context of a rewriting of the concepts of criminal procedural law.

Based mainly on the social evolution, which, of course, cannot be neglected by the legislation in this area, the principle of opportunity succeeds, but also with much controversy, among the fundamental principles of the Romanian criminal process.

As stated in the Report, "the permission granted to prosecutors in a large part of the world's states to apply some extra-legal considerations $s^{52}$ is a recognition that, in a society where there are competing interests and values, they must be reconciled, and the prosecutor is probably in the best position to operate a cost/benefit analysis regarding a possible prosecution or continuation of criminal prosecution." 53

In United States of America, this principle entrust the prosecutor with the discretionary choice of whether or not to prosecute a case. ${ }^{54}$

The opportunity principle "allows the prosecutor to dismiss a case despite sufficient evidence to charge when, according to his/her asseessment, a prosecution would not be in line with the public interest. Thus, the opportunity principle accepts that not all crimes may deserve prosecution, trial and, ultimately, punishment. By doing so, the opportunity principle provides prosecutors with leeway to determine the criminal enforcement policy of the day." 55

\footnotetext{
52 We will observe in our analysis that these considerations are not exactly „extralegal”, the appreciation of the opportunity being guided by the principle of legality, and the criteria of the public interest being defined by the law

53 Report of P.I.C.C.J., Short references on theoretical and practical approaches made by P.I.C.C.J. since the entry into force of the New Codes in order to understand and apply the principle of opportunity correctly and uniformly, p. 12, online at [www.mpublic.ro], accessed on 27. June 2016

54 Brown, D. C.; Turner, J. I.; Weisser, B., Prosecution in common law and civil law jurisdiction, The Oxford Handbook of Criminal Process, Oxford University Press, U.S.A., 2019, p. 151

55 Ibid.
} 
In the U.S., US Attorney's Manual Title 9 - Art. $9^{56}$ establishes that the prosecutor, when considering the opportunity, "to decide on the renunciation of the accusation due to the lack of a substantial federal interest, will consider all the relevant considerations, including:

1. federal law enforcement priorities;

2. the nature and seriousness of the crime;

3. the discouraging effect of the trial;

4. the degree of guilt of the person towards the deed;

5. the criminal record of the person;

6. the person's willingness to cooperate in investigating or prosecuting others;

7. the probable conviction or other consequences of the conviction. ${ }^{57}$ "

It is important to note that the list mentioned above is exemplary in nature and is not limiting, and the analysis of these criteria must be performed as a whole. Basically, the recourse to both the mentioned criteria and to other criteria depending on the specific circumstances of the case, must outline the lack of public interest in the continuation of the federal investigation.

In Canada, with the same reasons as in the U.S. or the United Kingdom, the DPP (Director of Public Prosecution) ${ }^{58}$ Guide has been developed. Among other things, when the Crown Counselor examines the opportunity for a criminal investigation, he must answer a series of questions: ${ }^{59}$ "if there is a reasonable likelihood of conviction based on the evidence that could be administered? In the case of an affirmative answer, should an indictment serve the public interest best? "

In the United Kingdom and Northern Ireland, a Code of Crown Prosecutors The Code for Crown Prosecutors - has been implemented at the level of prosecutors. ${ }^{60}$ In its contents, art. 3 mentions that "prosecutors, police or investigating agencies decide whether or not to accuse a perpetrator based on the provisions of the Crown Prosecutors Code, as well as the indications in the guidelines on the accusations elaborated by the Director of Public Prosecution (DPP).”

\footnotetext{
56 Report of P.I.C.C.J., p. 14, online at fwww.justice.gov], accessed on 28. June 2016

57 Ibid.

58 Public Prosecution Service of Canada, online at [www.ppsc-sppc.gc.ca], accessed on 28. June 2016

59 The aforementioned aspects were presented in detail and in the Report of P.I.C.C.J., p. 16 and next

60 Online at [www.cps.gov.uk], accessed on 29. June 2016
} 
If, previously, regarding the US legislation, I mentioned the so-called test of the prosecution decision, this time the legislative regulations designate a Full Code test. This implies, therefore, both the analysis of the probationary concerned in order to verify the extent to which it is capable of leading to a conviction, but also the subsequent verification of the public interest in conducting the investigations.

The criteria according to which this interest is determined are set out in the Code,

${ }^{61}$ the judicial bodies being forced to answer several questions:

1. How serious is the crime committed?

2. What is the type of guilt of the suspect?

3. What are the circumstances and the injury caused to the victim?

4. Was the suspect's age under 18 years of age?

5 . What is the impact of the crime on the community?

6 . Is the accusation and prosecution a response commensurate with those previously established?

7. Should information sources be protected or not?

In Spain, the criminal procedural law refers to the inapplicability of the principle of opportunity in the case of offenses for which the criminal action is initiated ex officio. At the same time, it is recalled about the principle of maximum simplicity, applicable in order to eliminate the non-essential acts and activities in order to fulfill the demands regarding the speed of the act of justice. ${ }^{62}$

In Italy, the prosecutor has the possibility of investigating any crime, but the existence of a criminal complaint does not oblige him to initiate the criminal prosecution. There is thus an appreciation of the criminal prosecution body, before any procedural action, which will balance the concrete damage and the public interest in the criminal prosecution.

The analysis of the principle of opportunity has also been made in the recent doctrine of other European states, an example in this respect being the Czech Republic.

\footnotetext{
${ }^{61}$ Presented widely and within the Report of P.I.C.C.J., p. 19 and next

62 Ibid.
} 
It was held ${ }^{63}$ that "the principle of legality and the principle of opportunity can be seen as contradictory at first sight because only the first mentioned is considered to be a traditional pillar of criminal procedures in continental European countries."

So it is important to determine the role of the principle of opportunity in the Czech criminal procedure and to summarize basic institutes which express this principle.

It is also important to determine which is the rule and which is the exception as to the applicability of the two principles. How much is the principle of opportunity activated? How dominant is it in relation to the general application of the principle of legality?

"The system of essential principles has to be understood as a coherent unit where individual principles are linked together and built on each other." ${ }^{64}$

Thus, the Czech system of criminal procedure does not refer to a particular principle in particular, but takes into account the principles of criminal procedural law as a whole. ${ }^{65}$

Very plastic, the authors refer to the relationship between the principle of legality and that of opportunity as a complicated relationship. ${ }^{66}$ It is mentioned ${ }^{67}$, that "the principle of opportunity can be characterised as a possibility given to the public prosecutor not to prosecute all the criminal offences which he gets to know about. The public prosecutor can use this possibility in cases where the prosecution would not be useful, effective or even unjust, which would cause that the purpose of the criminal procedure would not be achieved."

We identify in that sense "the motives of regulating opportunity according to the Polish lawyer Cieślak: a procedural and material motive. Procedural motive occurs while prosecuting minor crimes, which often results in inefficiency of criminal procedure because pursuing the whole criminal process with engaging the court

63 Kristková, A.; Kandalec, P., The Principle of Opportunity in the Czech Criminal Procedure Code, p. 239, [www.studiaiuridica.umcs.pl], accessed on 20.March 2020

${ }^{64}$ Ibid., p. 240

65 "The essential principles have to be interpreted in the essence of the Constitution and the Charter of Fundamental Rights and Freedoms. A very specific role plays the provision of the Art. $₫ 4$ of the Charter which states that while employing the provisions concerning limitations upon the fundamental rights and freedoms, the essence and significance of these rights and freedoms must be preserved. Such limitations shall not be misused for purposes other than those for which they were enacted. The Criminal Procedure Code (CPC) undoubtedly is a norm providing the mentioned limits."

${ }^{66}$ Kristková; Kandalec, op. cit, note 63, p. 243

67 Ibid. 
does not pay off. On the other hand, the material motive emphasizes the possible injustice of criminal proceedings at minor crimes." ${ }^{68}$

The authors manage to identify three essential elements in the analysis of the opportunity:

a. discontinuing of criminal procedure due to lack of public interest;

b. diversions as a result of a weakened public interest;

c. new concept of opportunity in a form of a cooperating witness.

a. The first element "is connected to the idea that the offenses of a less gravity should not be prosecuted if there is lack of public interest, in the most cases it means that prosecution is not worthy. The Czech Criminal Procedure Code also knows such provisions. A public prosecutor can discontinue a criminal procedure if it is clear that the goal of the criminal procedure was already achieved (in brief - because the facts of the case prove that the committed crime is of a lower gravity than other crimes of this kind)." ${ }^{\circ 9}$

b. The second element - the diversions - "definitely constitute a more simple procedure of achieving justice at minor offenses but, at the same time, they are an expression of a restorative justice concept which prefers rehabilitation of criminals to strict punishing them by the sentence of imprisonment. The Czech CPC distinguishes among the following kinds of diversions11: - conditional discontinuing of criminal procedure, - agreement on guilt and punishment." ${ }^{\prime 70}$

c. The third element - cooperating witness - "is a typical instrument of a new pragmatic use of opportunity. ${ }^{71}$ Weigend states that the increase in complicated organized crime and difficulties in obtaining evidence induced the situation that the state bodies resigned to fulfil the essential purpose of criminal procedure and chose to trade with justice by using the institute of a crown witness." 72 This institute serves for simpler revealing of organized crime where in many cases the facts of the case cannot

68 M. Cieślak, Polska procedura karna. Podstawowe zatożenia teoretyczne, Warszawa 1984, p. 292 apud Kristková; Kandalec, op. cit. note 63, p. 243

69 Kristková; Kandalec, ibid., p. 244

70 Ibid., p. 245

71 The authors refer to Ambos, K. International Criminal Procedure - Adversarial, Inquisitorial or Mixed?, International Criminal Law Review, no. 3, 2003, p. 18

72 Ibid., p. 247 
be revealed by other means than by using somebody from the inside of such an organized group.

Following the analysis of the system of Czech criminal procedural law, by referring to the analysis of the principle of opportunity, it is appreciated that the principle of opportunity provides an effective possibility how to deal with overloaded justice. Based on this fact, the principle of opportunity should be considered as a complementary principle to the principle of legality.

Therefore, like domestic law in Romania, the analysis of the public interest, by activating the opportunity, is not bounded by legality. This is due to the idea of legality in any point of the criminal process, regardless of the specific institution that becomes applicable.

Therefore, both the analysis of the Romanian system of procedural law and of other states, such as the Czech Republic for example, shows that, in fact, the socalled conflict between the principle of opportunity and that of legality appears rather as a perfect couple. The two principles are drawn together, the opportunity being based on its legality. Any solution ordered by the judicial bodies, even if it is determined as a result of activating the opportunity, is based on a series of rules provided by law (the principle of legality).

In the Lithuanian law system ${ }^{73}$, "it is recognised that modern criminal proceedings embrace a wide range of procedural forms, with a tendency toward the widening of the opportunities for the application of simplified forms of criminal proceedings. The exercise of the discretionary criminal prosecution as an expression of the principle of purposefulness (expediency) is on of the methods of resolving a criminal conflict in criminal procedure. The marked tendency of the new Criminal procedure code of Lithuania (2003) is that there are wide possibilities for terminating the pre-trial investigation (Article 212 of CCP). The author concludes that the regulation of alternative forms of settlement of criminal conflicts in the Lithuanian law of criminal procedure is substantially in line with the global trends of criminal proceedings development."

The liberalisation of criminal law and criminal procedure allowed "alternative measures" to be legalized and applied. ${ }^{74}$

73 Ažubalyte, R., Alternative Methods Of Resolving A Criminal Conflict In Criminal Procedure Of Lithuania, Days of Law: the Conference Proceedings, 1. edition. Brno : Masaryk University, 2009, p. 1

74 Ibid., p. 2 
We note that the criminal procedure law of Lithuania also allows the use of alternative means to the classical process, in order to resolve the conflict of criminal law, departing from the classical conception.

And the German law allows the prosecutor to assess the public interest, filtering out the less important cases and thus giving alternative solutions to the trial. ${ }^{75}$

\section{PRACTICAL ISSUES IN DOMESTIC LAW IN ROMANIA}

A controversial example is that, even if the prosecutor realized the application of the principle of opportunity, having a solution of renouncing the criminal prosecution, the judge, being invested with the analysis of the soundness and legality of the solution, considered that an even more favorable solution to the suspect is required, that of the classification.

We note in the example that we are going to present a situation where, in practice, the prosecutor "rushed" to appreciate the lack of public interest, given that he had at hand a much more "advantageous" solution to the suspect - the classification by reference to the lack guilt.

This example shows that the principle of opportunity should not be applied only as a subsidiary, when a classification solution cannot be ordered, the fact investigated covering all the conditions of a crime, but lacking the public interest in continuing the investigations.

By the application registered on 02.07.2018 in the role of the Timisoara Court under no. $17195 / 325 / 2018^{76}$, The Prosecutor's Office attached to the Timisoara County Court requested the confirmation of the ordinance from 26.06.2018 for renouncing the criminal prosecution in the file no. 7135 / P / 2017.

It was shown that by order dated 14.07.2017, it was ordered to start the criminal prosecution in rem for the offense of putting into circulation or driving on public roads of a vehicle or tram not registered or registered provided by art. 334 para. $1 \mathrm{CP}$, and subsequently, by the ordinance of 05.04 .2018 of the Prosecutor's Office attached to the Timisoara Court, arranging for further criminal prosecution against the said S.I. under the aspect of committing the offense of putting into circulation or driving on public roads an unregistered or unregistered vehicle or tram provided by art. 334 para. $1 \mathrm{CP}$, stating that, on 14.07.2017, around 3:40

\footnotetext{
75 See Damaska, M., The Reality of Prosecutorial Discretion: Comments on a German Monograph, Faculty Scholarship Series, 2011, p. 29, online at [www.digitalcommons.law.yale.edu], accessed on 11. June 2020

76 Unpublished
} 
pm, it was found driving the Mercedes Benz brand car with the registration number of the trial (Italy) Will pS 1234 on DN 59, km.8, on the radius of the city of Timişoara, from the direction of Şag towards Timişoara. Following the checks carried out by the police, it was found that the car was cleared from circulation by the Lithuanian authorities on 22.09.2016, and the registration plates of evidence (Italy) Va pS 1234 are not included in databases for registration in Italy.

Analyzing the documents and works of the file, the preliminary chamber judge holds that according to art. 318 para. 12 et seq. CPP, the order of the prosecutor ordering the renunciation of criminal prosecution is transmitted, for confirmation, within 10 days from the date on which it was issued, to the preliminary chamber judge from the court to whom, according to the law, the competence to judge the case in the first instance.

According to the provisions of art. 318 para. 15 Code proc.pen., The preliminary chamber judge verifies the legality and the soundness of the solution of renouncing the criminal prosecution on the basis of the works and the material from the criminal prosecution file and of the new documents presented and, by the conclusion, admits or rejects the request for confirmation made by the prosecutor.

In case he rejects the confirmation request, the preliminary chamber judge rescinds the solution of renouncing the criminal prosecution and can order the classification, according to the provisions of art. 318 para. 15 lit. b Code proc.pen.

The preliminary chamber judge finds that in this case the priority analysis of the incidence of the impediment to the commencement of the criminal action is required prev. of art. 16 paragraph 1 bed $b$ thesis II Code proc.pen - the deed was not committed with the guilt stipulated by the law.

Thus, the preliminary chamber judge finds that the suspect S.I. was found driving the Mercedes Benz car with the registration number (Italy) Va pS 1234 on DN $59, \mathrm{~km} .8$, on the radius of the city of Timisoara, from the direction of Şag to Timisoara. Following the checks carried out by the police, it was found that the car was cleared from circulation by the Lithuanian authorities on 22.09.2016, and the registration plates of evidence (Italy) Va pS 1234 are not included in databases for registration in Italy.

Regarding the offense retained in its task, that of putting into circulation or driving on public roads an unregistered or unregistered vehicle or tram provided by art. 334 para. 1 PC, the preliminary chamber judge finds that under the aspect of the objective side, the conditions for taking criminal responsibility are fulfilled. 
Thus, as a result of the checks, it turned out that the license plates mounted on the car driven by the suspect were not included in the registration database, being valid only in Italy, San Marino, Germany and Austria.

However, from the perspective of the subjective side, the preliminary chamber judge finds that the suspect did not commit the deed intentionally, not watching or accepting the production of the socially dangerous outcome.

Thus, the evidence administered during the criminal investigation phase outlines the absence of the suspect's intention regarding the driving action on the public roads of an unregistered vehicle.

In this regard are the statements from the file, the suspect stating that he took the car from his son, the owner of the car, having his heel and not knowing that the registration plates are not valid. He mentioned that his son borrowed his car for short distances.

The suspect's statement is also supported by the statement of the witness C.L. (f. 22), a police officer, who specified that the suspect said after stopping that he did not know the numbers were not valid and the car belonged to his son V.A., who assured him that it was okay.

In the same sense is the statement of witness V.A. (f. 29) which stated that he had transmitted all the documents to his father to the car, passing through countless times or the border without the police to find any problem.

Also, the preliminary chamber judge finds that, according to the address M.A.I. - I.G.P.F. - The Oradea Contact Point (f. 9), addressed to the Center for International Police Cooperation, the registration numbers used by the suspect are valid in Italy, as well as in the other countries with which it has signed bilateral treaties, such as San Marino, Germany, Austria. In these circumstances, the vehicle, thus registered, has or does not have the right of movement in relation to the national legislation of each state and the acceptance of this type of registration numbers.

Therefore, the preliminary chamber judge finds that there is a need for a reasonable proportion regarding the obligation of the drivers to ensure that they comply with the legal requirements in the road matters and to bring them to criminal liability for non-compliance with the rules.

Thus, it appears from the file data that the suspect has done all the reasonable diligence in such a situation, making sure that he respects the legal provisions when he took the car from his son. 
In this sense, the analysis of the guilt in criminal matters must be anchored in the factual, concrete reality, by reference to a diligent driver, but in a reasonable and predictable way.

However, the preliminary chamber judge finds that the suspect S.I. did not follow or accept the production of the result, being the case of preventing the criminal action in respect of the guilt provided by law.

The preliminary court judge finds that the evidence administered in the criminal prosecution phase outlines the lack of intent in the act of the suspect by the S.I.

For the foregoing, the preliminary chamber judge will reject the request to confirm the solution of renouncing the criminal prosecution formulated by the Prosecutor's Office attached to the Timisoara Court.

Pursuant to art. 318 para. 15 lit. b Code proc.pen., will order the cancellation of the ordinance of renunciation to the criminal prosecution dated 26.06.2018 issued by the Prosecutor's Office attached to the Timisoara Court in the file no. 7135 / P / 2017 in the aspect of committing the offense of driving an unregistered vehicle, provided by art. 334 para. 1 Criminal Code, against the suspect S.I.

Pursuant to art. 318 para. 15 lit. b rap. in art. 16 paragraph 1 bed b thesis II Code proc.pen., will order the classification of the case having as object the offense of driving an unregistered vehicle, provided by art. 334 para. 1 Criminal Code, against the suspect S.I.

The case-law example outlined above highlights the obligation of the case prosecutor to order a closing solution whenever it finds the existence of one of the cases stipulated by Art. 16 Code of Criminal Procedure, even if the conditions for dropping the criminal investigation provided by Art. 318 Code of Criminal Procedure would be fulfilled.

It is important to stress that a solution of closure is prevailed over the solution of relinquishing the prosecution in the light of the consequences of the solution.

The situation premiss for a solution to waive prosecution is the very existence of the crime. If, for example, the prosecutor finds that the act does not meet the constituent elements of an offense, he will order the case to be closed, not to drop the criminal investigation. 


\section{BETWEEN CONFIRMING AND DISPROVING THE SOLUTION OF RELINQUISHING THE PROSECUTION - JUDGE'S ANALYSIS}

In a case before the Timis Court ${ }^{77}$, the Preliminary Chamber Judge found that, in relation to the actual circumstances of the commission of the offence, the object of the infringement and the resulting result, having regard to the existence of a manifest disproportion between the costs incurred by the criminal proceedings and the seriousness of the prosecutions caused by the offence, there is no public interest in the pursuit of the present offence. Thus, the act committed consists of mounting a pipe from the PPR on the ceiling of the common corridor, with a view to supplying water to its commercial space. The act was not carried out using means such as to disturb public order and tranquility or create a sense of uncertainty or fear among the co-locators. The purpose of the works was to ensure the supply of water to commercial space, and the consequences are of a non-patrimonial nature. Furthermore, the suspect had a collaborative attitude with state institutions.

In another case ${ }^{78}$, the judge found that it is true that in relation strictly to the manner and circumstances of the commission of the act, the result produced, materialised in the relatively small damage, i.e. 986,62 lei, fully recovered, the act affects the social values defended by criminal law. However, the perpetrator is known, and his criminal record shows his conviction for an impressive variety of crimes. In relation to the rich criminal activity of the suspect it can no longer be relevant that he had an attitude of recognition and regret after the discovery of the crime committed. Consequently, the court rejected the request to confirm the waiver of the criminal investigation filed by the Prosecutor's Office attached to the Timisoara Court and, consequently, abolished the order for relinquishing the prosecution dated 08.06.2017 issued by the Prosecutor's Office attached to the Timisoara Court in case no.xxxxxx/P/2016 and ordered the referral of the case to the prosecutor in order to complete the criminal investigation in respect of the commission of the offence of theft provided by Art. 228 par. 1, with the application of Art. 41 para. 1.

A similar aspect to both of the above-mentioned reasonings is that of the person of the perpetrator, in relation to his criminal past, but also to the collaboration with judicial bodies after the commission of the act.

Decision no. 446/2017 of 19.07.2017 of the Timis Tribunal, unpublished

Decision no. 1219/2017 of 19.10.2017 of the Court of Appeal Timisoara, unpublished 
Thus, certain circumstances outside the actual act, which are related to the person of the offender, are thus highlighted, determining circumstances in the analysis of the public interest.

What follows is a varied caselaw in the procedure of confirmations or infirmations of solutions to waive the criminal investigation, and the conclusion is that for the same type of act, committed in similar circumstances, different solutions can be ordered, depending on the person of the perpetrator.

\section{CONCLUSIONS}

The basic rules of the criminal process are norms of criminal procedure with a character of fundamental principles, these representing the expression in the form of legal norms of the content of the conception and the principles of criminal procedural policy that serve to elaborate the Code of criminal procedure. ${ }^{79}$

These words still retain their essence today, but the social evolution, periodically determining the reinforcement of the mentioned principles, thus giving rise to current norms of law, appropriate to the times in which we live.

If some time ago the accomplishment of the criminal justice did not conceive the deviation from the principle of officiality only in totally exceptional situations ${ }^{80}$, at present, we are in the presence of a rethinking of the purpose of the criminal prosecution.

Thus, the obligation of the judicial bodies to carry out ex officio the documents necessary to carry out the criminal trial is rewritten, the exceptions from this rule becoming more frequent and becoming alternative solutions to the criminal prosecution.

Social discipline played a rather important role, but only partially, the change in attitudes coming from the state. Time has proved that not only the individuals targeted by criminal law must show a change of attitude, but even those who legislate on behalf of the state, and then those who effectively enforce the criminal rules. Reporting on the criminal phenomenon reaches a turning point, which follows from this on focusing on a justice system concerned about the long-term social impact.

\footnotetext{
79 In this regard, see Dongoroz, V. et al., Theoretical explanations of the Romanian Code of Criminal Procedure. The general part, vol. I, Ed. Academy - Institute of Legal Research, Bucharest, 1975, p. 40

80 An example in this regard is the offenses for which the initiation of the criminal action is carried out at the prior complaint
} 
In particular, with the effective application of the new criminal procedural provisions starting on 1 February 2014, it takes place among the rules of criminal judicial investigations, not shy, the principle of opportunity being expressed mainly in the way of regulating the institution's dismissal of the criminal investigation.

The assessment of the ordering of such a solution ${ }^{81}$ is crystallised around the analysis of the public interest, by reference both to the act committed, to its consequences, but also to the person who committed it, in the situation in which the author is known.

We can say that opportunity also works in reverse: It is appropriate to continue the prosecution and refer the matter to the court, with the public interest demanding that the author be punished. Therefore, even if modern doctrine, by constantly referring to the principle of opportunity, examines its application mainly by reference to the solution to waive the prosecution, we consider that the broad view of this principle must take into account the other side of it - the opportunity to pursue the prosecution (active opportunity), which, in fact, is not an exception to the principle of officiality.

The aforementioned theory, leading the opportunity on the two planes, may seem nonsense, but this is supported by the very way in which judicial bodies appreciate the public interest.

The distinction between the modalities of opportunity shall be made according to the outcome of the public benefit test. ${ }^{82}$

\section{REFERENCES}

\section{BOOKS AND ARTICLES}

1. Ambos, K., International Criminal Procedure - Adversarial, Inquisitorial or Mixed?, International Criminal Law Review, no. 3, 2003

2. Ažubalytė, R., Alternative Methods Of Resolving A Criminal Conflict In Criminal Procedure Of Lithuania, Days of Law: the Conference Proceedings, 1. edition. Brno: Masaryk University, 2009

3. Brown, D. C.; Turner, J. I.; Weisser, B., Prosecution in common law and civil law jurisdiction, The Oxford Handbook of Criminal Process, Oxford University Press, U.S.A, 2019

4. Cieślak, M., Polska procedura karna. Podstawowe zatożenia teoretyczne, Warszawa 1984

\footnotetext{
81 The solution to relinquish the prosecution (classification in opportunity) can only be ordered by the prosecutor, with criminal investigation bodies having only the possibility of drawing up a report with a proposal in this regard

82 Opportunity test
} 
5. Damaska, M., The Reality of Prosecutorial Discretion: Comments on a German Monograph, Faculty Scholarship Series, 2011

6. Deleanu, I., Constitutional Institutions and Procedures, vol. II, Lugoj, 2000

7. Dongoroz, V et al., Theoretical explanations of the Romanian Code of Criminal Procedure. The general part, vol. I, Ed. Academy - Institute of Legal Research, Bucharest, 1975

8. Graur, M.C., Criminal action - between official and opportunity, Ed. Hamangiu, Bucharest, 2019

9. Mihai, G., The foundations of law. The theory of legal responsibility, vol. V, Ed. C.H.Beck, Bucharest, 2006

10. Proal, L., Le crime et la peine, quatrieme édition, Librairie Félix Alcan, Paris, 1911

11. Udroiu, M. M., Code of criminal procedure. Comment on the articles, Ed. C.H. Beck, Bucharest, 2015

12. Udroiu, M., It's criminal procedure, The special part, 4th Edition, Ed. C.H. Beck, Bucharest, 2017

13. Volonciu, N., Uzlău, A., The Code of criminal procedure commented, Ed. Hamangiu, Bucharest, 2014

\section{NATIONAL AND INTERNATIONAL COURTS DECISIONS AND ACTS}

1. Opinion no. 9 (2014) of the Advisory Council of European Prosecutors

2. The Rome Declaration

3. Explanatory note to Opinion no. 9 (2014) of the Advisory Council of European Prosecutors

4. D.C.C. No. 1/1994, M. Of. No. 69 of 16 March 1994

5. D.C.C. No. 129/1995, M. Of.nr. 105 of 23 May 1996

\section{WEBSITE REFERENCES}

1. Public Prosecution Service of Canada, [www.ppsc-sppc.gc.ca], accessed on 28. June 2016

2. Kristková, A.; Kandalec, P., The Principle of Opportunity in the Czech Criminal Procedure Code, [www.studiaiuridica.umcs.pl], accessed on 20. March 2020

3. Report of P.I.C.C.J., Brief references to theoretical and practical approaches made by the P.I.C.C.J. since the entry into force of the $\mathrm{New}$ Codes in order to understand and apply the principle of opportunity correctly and uniformly, [www.mpublic.ro], accessed on 04. July 2016

4. Rapport public du Conseil d'État, Etudes at documents, no. 5, 1999, [www.conseil-etat.fr], accessed on 30. January 2018

5. 4. Sunday Times c. Great Britain, April 26, 1979, Parag. 49, Kokkinakis c. Greece, May 25, 1993, Parag. 40, Cantoni c. France, November 15, 1996, Parag. 32, Rekvenyi c. Hungary, Parag. 34, [www.echr.coe.int], accessed on 04. July 2016

6. Groppera Radio AG and others c. Switzerland, 28 March 1990, Parag. 68, [www.echr.coe. int], accessed on 04. July 2016 
7. Kokkinakis c. Greece, 25 May 1993 and Cantoni c. France, 15 November 1996, [www.echr. coe.int], accessed on 04. July 2016

8. S.W. c. United Kingdom, 22 November 1995, Parag. 36, [www.echr.coe.int], accessed on 04. July 2016

9. Dragotoniu and Militaru-Pidhorni c. Romania, 24 May 2007, Parag. 35 and next, [www. echr.coe.int], accessed on 04. July 2016

10. [www.echr.coe.int], accessed on 30. January 2020

11. [www.mpublic.ro], accessed on 30. January 2020

12. [www.conseil-etat.fr], accessed on 30. January 2020

13. [www.studiaiuridica.umcs.pl], accessed on 30. January 2020

14. [www.digitalcommons.law.yale.edu], accessed on 30. January 2020 